\title{
Time to take our medicines, seriously
}

Citation for published version (APA):

Urquhart, J. (1992). Time to take our medicines, seriously. Rijksuniversiteit Limburg. https://doi.org/10.26481/spe.19920403ju

Document status and date:

Published: 03/04/1992

DOI:

10.26481/spe.19920403ju

Document Version:

Publisher's PDF, also known as Version of record

\section{Please check the document version of this publication:}

- A submitted manuscript is the version of the article upon submission and before peer-review. There can be important differences between the submitted version and the official published version of record.

People interested in the research are advised to contact the author for the final version of the publication, or visit the DOI to the publisher's website.

- The final author version and the galley proof are versions of the publication after peer review.

- The final published version features the final layout of the paper including the volume, issue and page numbers.

Link to publication

\footnotetext{
General rights rights.

- You may freely distribute the URL identifying the publication in the public portal. please follow below link for the End User Agreement:

www.umlib.nl/taverne-license

Take down policy

If you believe that this document breaches copyright please contact us at:

repository@maastrichtuniversity.nl

providing details and we will investigate your claim.
}

Copyright and moral rights for the publications made accessible in the public portal are retained by the authors and/or other copyright owners and it is a condition of accessing publications that users recognise and abide by the legal requirements associated with these

- Users may download and print one copy of any publication from the public portal for the purpose of private study or research.

- You may not further distribute the material or use it for any profit-making activity or commercial gain

If the publication is distributed under the terms of Article $25 \mathrm{fa}$ of the Dutch Copyright Act, indicated by the "Taverne" license above, 


\title{
Time to Take Our Medicines,
}

\section{Seriously}

\author{
REDE
}

Uitgesproken bij de aanvaarding van het ambt van bijzonder hoogleraar in de

Farmaco-epidemiologie

aan de

Rijksuniversiteit Limburg

op vrijdag 3 april 1992

door

Dr. J. Urquhart

Lecture given by

Dr. J. Urquhart

on the occasion of his appointment

as Professor of Pharnaco-epidemiology

at the

University of Limburg

Maastrich"

Frriday, April 3, 1992 



\section{Honored colleagues, dear friends, ladies and gentlemen:}

My title has several meanings. There are, after all, thirty recognized meanings of the English verb "take." I'll mention just several.

First, we have to take medicines seriously - that is, we have to be serious in how we value them - because they are so widely used and so powerful. The prescribing of medicines is the principal interventional weapon in medical care. Collectively, medicines have had powerful impact. Together with a strong sanitary infrastructure, they have literally reshaped our society with astonishing rapidity.

Less than a century ago we were a society with high birth rates; few reached old age because so many died young or in middle age. Today we are a society with low birth rates; most reach old age because so few die young or in middle age.

It would be catastrophic if the diseases and death rates of the "good old days" suddenly returned. We in the developed countries take for granted the medicines and other medical techniques that have lifted us so quickly out of that morass. Forgetting our newly gained freedom from early death, we complain about the costs of medical care and the risks of modern life.

So, a second meaning of my title derives from the meaning of "take" in the sense of "understanding," as in "I take your point." It is time to understand our medicines, their uses, risks, and benefits, and not just to take them for granted.

We may take our medicines for granted, but we don't take them very reliably. Medical care relies heavily on patients to self-administer medicines, but there is a high prevalence of incortect self-administration, also known as poor patient compliance. It complicates medical care and confuses clinical research on new medicines. Physicians don't recognize poor compliance very well, so there is a basic problem in the quality of both outpatient care and outpatient trials of new medicines. 


\section{Meten is Weten}

Attack on these quality problems begins by recognizing the truth of the Dutch proverb, "meten is weten": measurement of outpatients' dosing is the basis for understanding, and under. standing is the basis for efficient action. Thus, we have to take seriously how people take their medicines in order to improve the quality and economics of both medical care and clinical evaluation of new medicines.

The first step in taking our medicines seriously is to analyze the nature of medicines.

\section{From a Philosophical to a Technological Concept of a Medicine}

Our basic concept of a medicine was shaped by an early idea in Greek philosophy that medicines have two fundamental attributes. One is their physical nature, called the rhizome, the Greek word for "root," and an apt term, because plants gave us most early medicines. The second attribute is the power inherent in the thizome to exert therapeutic or toxic actions when administered to humans. The Greek word for this power is dynamis (buvaus).

The Latin translation of "dynamis" is "potentia." Thus, our terms "dynamic" and "potential," which today are rich in both literary and technological meanings, have their origins in the earliest concept of a medicine. Today, the term "therapeutic potential" conveys the meaning of "dynamis." Therapeutic potential is only revealed when the medicine is administered.

The conception of a drug as rhizome and dynamis prevailed until technology began putting truly powerful medicines into doctors' hands, most of which have come into use since 1945. Medicine had been a primitive att until the microbiologic revolution of the 1880 s, for it lacked understanding of bacteria and their then pre-eminent role in morbidity and mortality. Jenner's vaccination in the 1790s showed that man could intervene to prevent a leading disease, but it was an empirical 
fix for one disease.

One of the first practical results of microbiologic knowledge was asepsis in surgery, which unleashed surgical innovation beginning in the 1890s. Surgery brought unheard-of intervention, overturning the Hippocratic injunction: primtum non nocere - above all, do no harm. Meanwhile, the non-surgical part of medicine remained a feeble art, with a few well-known exceptions like insulin, until the first group of anti-microbials .. sulfa drugs, penicillin, and streptomycin -- demonstrated a previously undreamed of therapeutic power.

Progress in chemistry and pharmacology advanced knowledge and pushed the concept of a medicine toward the technological, but conceptual change was precipitated by two dramatic events, one positive, the other negative.

The positive event was the development of penicillin. Its unprecedented power is illustrated in a story I heard as a surgical house officer 30 years ago at the Massachusetts General Hospital. The first patient treated with penicillin at that famous institution was a nursing mother with streptococcal mastitis - a condition rarely seen today. She was in grave condition when admitted one afternoon in 1944. She was seen by the residents and the visiting surgeon, Dr. Nathaniel Faxon, later the hospital's Director. The patient's situation seemed hopeless, so they decided to try this new penicillin. At surgical rounds the next moming, when they came to the patient's bed, Dr. Faxon saw a healthy looking woman having her breakfast and asked, "What happened to the patient with mastitis?" "This is she," said the resident. "Nonsense," said Faxon. "No drug could possibly do that."

The negative event was the catastrophe of thalidomide. The images of babies with deformed limbs are still vivid, thirty years later. No one had thought a drug could possibly do that, either.

The practical and psychological impact of unprecedented medicinal power changed our conception of a medicine. Two fundamental attributes have expanded to four. The rhizome has been split into two parts, the drug substance and the dosage form. The dynamis - therapeutic potential -- remains qualitatively unchanged, but has powerful new quantitative attributes. 
III name the fourth attribute later, and only note that it bears the main responsibility for today's high cost of new medicines.

\section{The Technological Conception of a Medicine}

\section{The Rhizome Transformed into Drug Substance and Dosage Form}

We now see that the rhizome presented the drug substance in a chewable dosage form. Medicinal chemistry has taught us to see the rhizome as a chemical jungle of thousands of different chemical substances, usually only one or a few of which can be called "drug substances," which are a particular class of "chemical substances" that have the power to elicit useful pharmacological actions when administered to humans or animals.

For precision, I use the term "drug substance" to refer to these chemicals, and "medicine" to refer to a pharmaceutical product. I am avoiding the term "drug" here, because it can mean both "drug substance" and "medicine."

\section{The Drug Substance}

"Drug substance" is a chemical concept in which the dynamis is crowded into the smallest possible physical form .. a pure, chemically homogeneous substance. The dynamis no longer lives in a big thizomal house, but in a riny molecular house, in which the architecture corresponds to that of a group of receptors in the body, where drug molecule and receptor fit together in the metaphor of two satellites docking together in space. The fitting together of drug molecule and receptor serves to trigger biochemical steps within the body that lead to drug action. Isolation of growing numbers of receptors has opened up the possibillty of quickly screening the receptorinteractions of chemical substances, giving a rapidly defined profile of each one s likely range of pharmacological activities.

In discussing medicines, it is conventional to focus most of 
the attention on the drug substance: how it was discovered, its molecular architecture, and, increasingly, the discovery of its receptors. My focus on therapeutics and pharmaco-epidemiol. ogy deals with events in patients and groups of patients; we cannot simultaneously focus on molecules. Therefore, I would ask you to think of the drug substance and its principal receptor in relation to the medicine as you would think of the tenor and soprano in relation to the opera. Without the tenor and soprano, there can be no opera, for those two alone can only give you a recital of arias. For the full dynamics of opera, other elements are required.

Others can tell you much more about drug substances. I will only add the point that the drug substance is often such a tiny amount of material that a single dose is too small to be handled reliably except in a laboratory. Thus, in taking apart the rhizome in order to track the dynamis to its molecular house, we created the need to build a new rhizome, now called ...

\section{The Dosage Form - and a New Type of Dynamis}

The dosage form is, first of all, a means to convey the correct quantity of drug substance conveniently to the patient tablets, capsules, aerosols, ointments, drops, and so forth. Once administered, it must release the drug substance so that it is reliably absorbed.

A bad experience with digoxin in the early 1970 s taught that undependable absorption means undependable action.

Drug delivery systems go several steps beyond the simple dosage form: they use membrane technology to control the rate of drug release in order to maintain drug levels in the body within ideal limits for a specified period of rime. Thus, a delivery system might be thought of as a dosage form that has itself a certain dynamis -- a functional program of drug release that plays out over time in a predetermined way to ensure the optimal timing of drug entry into the body.

"Optimal timing" can mean many things: gradual rather 
than all at once; some now, then none for a while, then some again later; a high rate at first, then a low rate later. There is a potentially infinite number of patterns that might provide optimal timing. Thus, there is a practical problem in how to identify optimal timing, but the underlying conceptual point is that the therapeutic potential of some drug substances can be substantially enhanced by dosage form design to achieve optimal timing. Indeed, a number of medicines now provided in delivery systern form illustrate how optimal timing has improved therapeutic potential: scopolamine for motion sickness, ${ }^{2}$ pillocarpine for glaucoma, ${ }^{3}$ and nifedipine for hypertension and angina pectoris. ${ }^{4}$

Improving therapeutic potential with rate-controlled delivery systems was a major focus of my work from 1971-85 when I was Principal Scientist at ALZA Corporation in Palo Alto, California. It was during this period that drug delivery systems went from concept to reality. I wrote many papers and made many inventions in this area, but two activities are noteworthy here.

One was my collaboration with Douwe Breimer and colleagues in Leiden in work which demonstrated that the therapeutic potential of nifedipine was greatly improved by constant-rate delivery. ${ }^{5}$ That discovery is the pharmacodynamic basis for formulating nifedipine in a rate-controlled drug delivery system and making, thereby, a much-improved medicine with a much lower incidence of side-effects previously thought to be inherent in the actions of nifedipine. ${ }^{4}$

The other was to have initiated and championed the devellopment of a family of osmotic pump delivery systems for use in experimental physiology and pharmacology. These products, often called osmotic minipumps, are now in their 16 th year of use by researchers all over the world, in all kinds of studies. The product bibliography now contains more than 2,500 papers. Withour these pumps, it is doubtful that Breimer and his colleagues would have been able to do the studies that first suggested the possibility of improving the therapeutic potential of nifedipine.

Product development in industry requires a large, multi- 
disciplinary team, making it difficult to give credit as one does in academic research. Four people deserve mention: the inventor was Dr. Felix Theeuwes; the product development team leaders were Dr. Su II Yum and Mr. Benjamin Eckenhoff; Mrs. Marie Barry directed the communications program needed to accelerate product use in multiple, specialized fields of research. The vision for this activity; which I shared with ALZA's founder, Dr. Alejandro Zaffaroni, was to provide the tools needed to explore and understand the topic to which we now turn, which is ...

\section{Dynamis, or Therapeutic Potential}

The old dynamis is still with us in the technological conception of a medicine. Now called "therapeutic potential," it has its own academic discipline called pharmacodynamics, which teaches that the actions of a medicine depend on dose quantity and dose timing. It further teaches that each medicine has an optimal regimen of dose quantity and dose timing giving the best balance of therapeutic benefit and unwanted side-effects.

The concept of an optimal regimen is both new and very old. In the Renaissance, Paracelsus taught that everything is a poison, it is only a matrer of dose -- even for pure water. Yet, many modern medicines, developed with the best modern methods, have come into the market at doses far higher than necessary. ${ }^{6}$ It then takes some years to get the best dose identified and accepted. That this happens is not a vindication of homeopathy, but merely a reminder that it can be a costly mistake to develop new medicines without a purposeful search to identify the optimal regimen of dose quantity and dose timing.

Captopril illustrates: its most commonly used doses are one-third to one-sixth the initially reconmended dose. Renal toxicity at the highest doses almost killed the product. ${ }^{6}$

Finding the optimal dose-timing is more complex, but can have great practical importance, as illustrated by the history of the two biggest cash products in the world pharmaceutical 
market, ranitidine and cimetidine, both used to treat peptic ulcers.

Cimetidine entered the market in the late 1970 s with a recommended dosage frequency of four times a day. This dosing schedule put it at a competitive disadvantage against ranitidine, which entered the market a few years later, at first with a twicedaily regimen, and later once-daily. The simpler regimen was one of the factors that helped ranitidine capture the leading share of the huge market for ulcer medicines. Several more years passed before the makers of cimetidine learned that, all along, their product had been equally effective given once or twice daily. Four times claily dosing was indeed necessary to maintain cimetidine levels in blood. Only later was it leamed that ulcer. healing does not require continuous presence of cimeridine in blood, thus allowing twice- or once-daily dosing. ${ }^{7}$

There is more to the optimization of dose-timing than deciding the number of daily doses. The real power of dosetiming is illustrated by the hormonal control of ovulation.

The hypothalamic neurohormone, $\mathrm{GnRH}$, regulates ovulation by stimulating the pituitary gland to secrete the hormone that triggers ovulation. This stimulatory action of $\mathrm{GnRH}$ depends in a very strict way on the timing of its secretion: brief pulses, about 5 minutes in duration, repeated ar approximately 90 minute intervals. Only in that very special pattern does it stimulate the pituitary to secrete the ovulating hormone. Ovulation ceases when the hypothalamus fails to maintain that secretory pattern. The result is infertility. One can induce ovulation by adminisrering GnRH, but it must be given in this very special time pattern. If it is given at constant rate, or with other time patterns, it does not work. Indeed, continuous administration of GnRH inhibits ovulation in normally ovulating women. Thus, GnRH can be either an activator or an inhibitor of ovulation, depending solely on dose-timing. ${ }^{B}$

In the molecular house of $\mathrm{GnRH}$, there lives not one dynamis, but two, with opposite natures: dose-timing decides which one prevails.

Endocrinology has valuable lessons to teach about modulation of hormonal actions by rate and timing of secretion. The 
hormones may be thought of as God's medicines; pharmacoliogists can learn divine lessons in pharmacodynamics by studying the dynamics of physiological regulation -. endocrinology, immunology and cell growth.

The dynamics of hormonal actions was the major theme of my work during the 1960s." During most of that decade I was Professor of Physiology in the School of Medicine at the University of Pittsburgh and had the good fortune to work in the department led by Enst Knobil, whose research in animals first identified the pulsatile secretion of $\mathrm{GnRH}$.

\section{Contending Paradigms}

It is not yet conventional wisdom to search for optimal regimens. Regimen optimization has tended to get short shrift in clinical research, and most clinical researchers pay little or no heed to patients' actual dosing when new medicines are being tested. For example, the results of most clinical trials of new medicines are still based on data averaged from all patients prescribed the medicine, whether or nor they actually took any. This all-patient averaging is prescribed by a statistical model, in the interests of simplicity of analysis and to avoid bias that: might enter because patients make their own decisions about how much drug to take, and when. From a pharmacodynamic perspective, however, this approach has been aptly described by Lewis Sheiner, as "bizarre." A major intellectual confrontation is looming in clinical research between those who see drug evaluation primarily as a test of the null hypothesis, and those who see drug evaluation primarily as means to develop optimal regimens and reliable estimates of therapeutic potential. It is a Kuhnian paradigm conflict.

\section{A Look at an Actual Dosing Record and its Clinical Correlates}

Some of the opportunities and problems of interpreting patients' actual dosing records are illustrated by reviewing some data. First, however, I want to remind you that I have both an intellectual and a commercial interest in this problem. In 
1985, Raymond A. Williams, Jr. and I co-founded APREX Corporation to pioneer the development of devices and services for measuring and analyzing outpatients' dose-timing. The devices integrate microcircuitry into pharmaceutical packaging to record date and time when the package is used in a manner indicative that dosing is occurring. A number of studies are now published based on their use. "I devote the majority of my time as Chief Scientist at APREX, and one-fifth of my time to the University.

Now let us turn to the dosing record of a patient of Professor Ellen Weber and Dr. Wolfgang Krüse in Heidelberg (Figure 1 at right). The record is quite different from the once-daily regimen prescribed. There were episodes of acute pulmonary congestion on the second and third Sundays, both requiring emergency care, and both immediately preceded by two days without any record of medicine having been taken. The electronic record showed that the medication event on the third Sunday occurred after the patient called for the ambulance.

The patient made these choices without asking or telling anyone. Her history at the time revealed nothing of this, so her doctors thought that her heart failure had gotten worse and treated her accordingly. Her doctors did not have this record at the time they were treating her. Todlay they could, but this was one of the very first uses of the electronic dosing monitors, and at that time it required a special computer to retrieve the data. Thus, her dosing record became evident only later.

What do we learn from it? The data tell us that the patient took the prescribed number of doses -- actually one extra - but with very poor dose-timing. The patient was well-managed except when dosing lapsed for more than two days -. a conclusion consistent with prior knowledge about diuretic actions in patients with heart failure. But how should we answer the question: Was the medicine effective?

We see two serious episodes of fluid retention in a patient prescribed a medicine meant to prevent fluid retention and its complications. If we didn't know the dosing record, we would conclude that the medicine was ineffective. But we do know the dosing record. If we consider only the number of doses she 


\section{Figure 1}

\section{Variable Dosing with Once-Daily Diuretic by a Patient with Moderately Severe Congestive Heart Failure}

$\begin{array}{ccccccc}\text { Mon } & \text { Tues } & \text { Wed } & \text { Thurs } & \text { Fri } & \text { Sat } & \text { Sun } \\ 3 & 1 & 1 & 0 & 2 & 1 & 1 \\ 2 & 1 & 2 & 1 & 0 & 0 & 0^{*} \\ 4 & 1 & 1 & 2 & 0 & 0 & 1^{*} \\ 2 & 0 & 1 & 1 & 1 & 0 & 1\end{array}$

Figure 1. Each number represents the number of daily medication events, measured by an electronically monitored medicine container that records time and date each time the container is opened and closed (MEMS ${ }^{\circledast}$, APREX, Fremont CA, USA, and Zug, $\mathrm{CH}$ ). On the assumption that each medication event (a cycle of opening and closing of the container) represents a dose taken, the numbers indicate the number of doses of a prescribed once-daily diuretic (hydrochlorothiazide plus triamterene) taken each day by the patient. Each successive row of numbers is a successive week. The asterisks on the second and third Sundays of the 4-week period indicate episodes of acute pulmonary congestion and dyspnea requiring emergency treatment. I am indebted to Prof. Weber and Dr. Krüse for permission to present these data, which were published by them in Eur J Clin Pharmacol 38:561-5,1990. 
took, we would also say that the medicine was ineffective. The data on dose-timing show the sequence of lapsed dosing and then clinical signs of fluid retention. The time sequence supports the conclusion that the medicine was effective, when taken. It also suggests the hypothesis that one day without dosing is forgiven, but two or more days without dosing leads to serious trouble.

\section{A Visionary's Extrapolation}

This is only one patient's story, so let's look further. As we do that, please note that I am giving you an unabashed visionary's view of where such information may lead us. The question we face is whether the sequence of events seen here reflects causality or coincidence. We know that this is not an unusual dosing pattern, for about a third of patients in longterm pharmaco-therapy show occasional 1-,2-, and 3-day interruptions in dosing -- "drug holidays." "Thus, we can expect to see other parients with this same condition who, on their own volition, are performing similar but not identical experiments in dose-timing; we happen to have been witness to this one because the medication event monitor revealed it.

To broaden our experience, suppose we were to identify patients with heart failure who had already been hospitalized once or twice for acute pulmonary congestion. Suppose we monitor their diuretic dosing for several months. At the end of that time, we collect the monitors and review each patient's dose-timing data together with the clinical record. Then we can see how often lapsed dosing occurred, how often acute pulmonary congestion occurred, and how they related to one another in time sequence. If the sequence seen here turned out to be infrequent, then we would be back where we started, with unexplained episodes of pulmonary congestion in patients with heart failure. However, if the sequence seen here is repeated many times, then we have reasonable confidence in the estimate that $2-3$ days of omitted diuretic dosing triggers pulmonary congestion in patients with moderately severe heart failure. 
If we could efficiently use that information to prevent such episodes, we could avoid a lot of needless health care costs. Two practical steps could be taken. The doctors who treat these patients would learn to probe more carefully for evidence of poor compliance, and not be too quick to prescribe stronger medicines. It would also catalyze efforts to prevent these lapses in dosing, with several possible approaches.

One approach would be to provide clear information that lapses in diuretic dosing are both common and risky, and to target that information to patients, families, caregivers, pharmacists, nurses, and doctors. A second approach might be to develop some technology to monitor for critical dosing lapses and give an appropriate alert to the patient or caregiver. Whatever steps we take to try to improve things, we measure their consequences, and use standard trials methods to evaluate their effectiveness. Meten is weten.

Skeptical purists could criticize such an effort for being based on an unproven hypothesis, and call for a randomized, controlled, appropriately blinded trial to test the hypothesis that 2-3 days lapse in diuretic dosing triggers pulmonary congestion. If we didn't have to meer ethical standards, we could, for example, ask patients with moderately severe heart failure to volunteer for a trial where their diuretic doses were replaced at randomly selected times with look-alike placebo dosage forms. However, I cannot imagine any ethical committee allowing such a trial. They might allow us, though, to bring patients into hospital and do some very limited maneuvers to see how salt and water balance change during brief periods of delayed dosing, well short of enough to risk pulmonary congestion. Even that design might not pass ethical review, and would probably not satisfy certain purists, but its real problem is that heart failure often improves just because hospitalized patients spend a lot of their time in bed. That often has a big enough beneficial effect to reduce the need for diuretic treatment. In that way, we could end up with either no experiment or one that is both costly and meaningless.

In this visionary extrapolation from a single case, you can see two contending approaches to clinical research. They are 


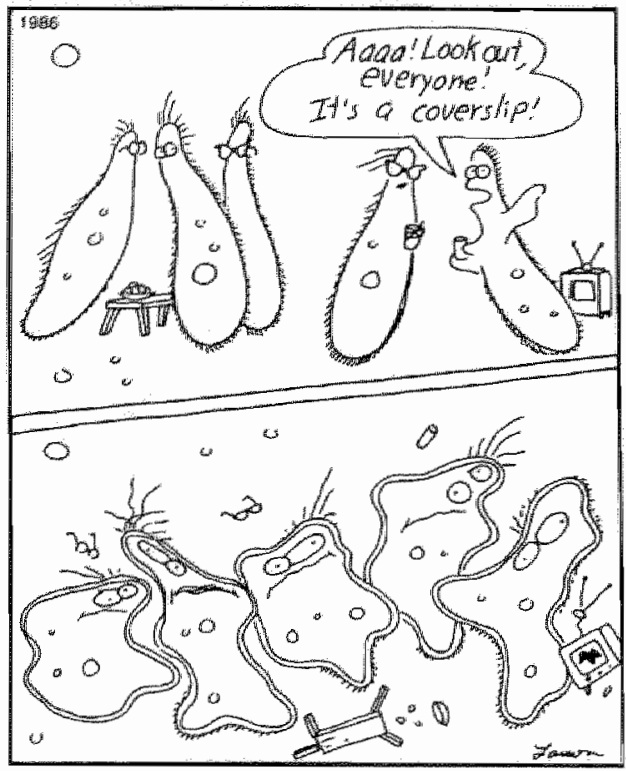

Litie on a muicroscope side

Figure 2. It is difficult to focus on microscopic life within a drop of water placed on a microscope slide. A cover slip creates a monolayer, and a uniform depth of field. As Gary Larson suggests here, simplicity of analysis can exact a heavy toll on reality. THE FAR SIDE copyright 1986 UNIVERSAL PRESS SYNDICATE. Reprinted with permission. All rights reserved.

epitomized by the great biological humorist, Gary Larson. Figure 2 (above) illustrates one of the main problems with randomized, controlled experiments: the cover slip simplifies analysis because it puts everything into one plane of focus, but with terrible distortion.

Figure 3 (at right) illustrates one of the main problems with observational studies: the subjects are reacting to circumstances in many ways that are unseen and uncontrolled. Both approaches are useful, and neither is complete. My vision for using spontaneous dose-timing measurements relies heavily on prior knowledge about the actions of the medicine involved, some coming from tandomized controlled trials, some coming from clinical experience and observation. Measurement of the time history of dosing opens a new window on better under- 
standing of therapeutic potential. I believe that applications such as those I have outlined will help us make better, faster, quantitative estimates to guide us toward the best uses of medicines.

You have now seen, though I have not described it as such, the fourth attribute of a medicine, which is ...

\section{Information}

Information is the fourth element in the technological conception of a medicine. There was always a modicum of information that attended any medicine, but in old times it was limited to a few words, e.g." "take prunes for constipation".

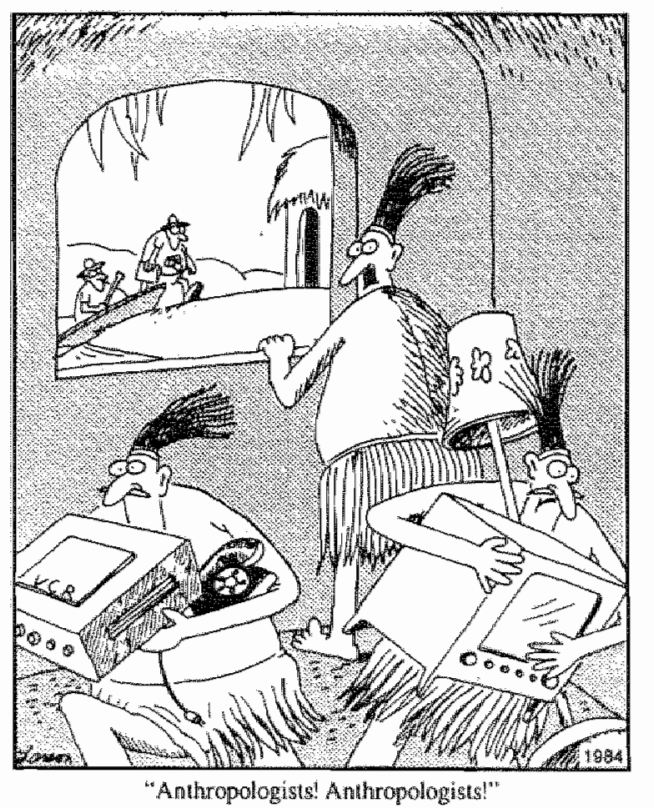

Figure 3. Observational studies take a lot of abuse, but, despite all their problems, that"s how discoveries are made. In this zany vignette, Gary Larson captures some of their worst problems. TIE FAR SIDE cartoon by Gary Larson is reprinted by permission of Chronicle Features, San Francisco, CA. Copyright 1984. All rights reserved. 
Today, an immense corpus of information is needed to answer all the questions asked about a new medicine. We can now see a societal side-effect of ever more powerful medicines: to stimulate ever more questions, mainly about therapeutic potential, in the form of risks versus benefits of taking the medicine. A fairsized truck is now needed to transport the volumes of information that comprise an application to register a new medicine for marketing.

The acquisition of information about the new medicine consumes most of the immense cost of discovery and development of a new medicine, the most recent estimate for which is $\$ 231$ million. ${ }^{12}$ In a certain sense, the development of a new medicine is a race to answer all the current questions before new questions are posed! More questions mean that more patent life is consumed in pre-market studies. The consequences ate higher prices and intensified marketing efforts to put the new medicine into the widest possible use as quickly as possible. The pricing of medicines is dominated by the cost to create the informational corpus.

It is not just the regulators who demand more information. The marketplace -- which means all of us - has steadily growing expectations for information about a new medicine. The quality of information on a new medicine is virtually a sine qua non for successful marketing.

The informational corpus is the focus of governmental regulation of prescription medicines. The scientific and medical quality of the informational corpus is important, but the crux is the balance between benefit and risk in using the new medicine. Second is an ongoing review to ensure that promotional claims for the medicine are consistent wirh its corpus of information.

The informational corpus never stops growing. The character of the information changes as clinical experience replaces formally designed trials, but growth continues. It is not clear who will pay to insure ongoing analysis of that growing informational corpus, which often becomes especially valuable just about the time a drug substance loses its patent protection and becomes, in the present system, an economic orphan. 
In respect to the crucial question of drug safery, it is not the pre-market trials, but the post-marketing use-experience that crucially defines the medicine's degree of safery. There are two basic reasons: numbers and types of patients.

\section{Numbers of Patients}

Pre-market studies only involve a few thousand patients. The number is growing, but it is inevitably limited, not only by economic resources, but by competition for patients at clinical centers qualified to meet increasingly strict standards for protocol adherence and record keeping.

\section{Types of Patients}

Trials are invariably designed with strict criteria for selecting patients according to type and severity of disease. Patients who have multiple diseases or who take multiple medicines are usually excluded from pre-market trials. Once the drug enters the market, however, usage expands to include patients with complex disease problems. The problems inherent in patients' disease problems are sometimes attributed, correctly or incorrectly, to the new medicine. How to tell which? It is a problem that I and my colleagues Hans Petri, Bert Leufkens, Jack Naus, Reinhilde Silkens, and Paulien Van Hessen, have addressed, using ...

\section{The Dutch Community Pharmacy as a Unique Informational Resource}

Several features make this so. First and foremost is the long history of the designated pharmacy requirement for patients insured by the Sickfunds. Second is the uniquely large size of Dutch pharmacies -- about 10,000 patients per pharmacy, compared to about 3,000 in other countries; size gives the economic base for computerization, which is now essentially complete. As in orher Continental countries, but unlike 
British or North American pharmacies, Dutch pharmacies focus on prescription medicines and are not distracted by a shop-keeping role of selling consumer products.

Patients who rely on a single pharmacy have a complete history of all their prescriptions in the pharmacy computer. This prescription history has been an undervalued resource. It was impractical prior to computerization of pharmacies. The designated pharmacy requirement created this record for Sickfunds-insured patients, but of course any patient who relies on a single pharmacy also has such a record. It brings together in one place prescriptions written by multiple doctors for the same patient. This record permits one to analyze, from a therapeutic perspective, the time patterns of usage of particular medicines: how medicines were prescribed, in what dosage, for how long, and in what relation to other prescribed medicines.

The computer ensures that every record is made anonymous before being made available for epidemiologic research. That is an absolute pre-requisite in all the work we have done. We have neither intention nor reason to intrude in any way on private matters of individual patients.

Analyzing prescription drug histories can show several important things. First, it can reveal useful information about the medical problems of patients prescribed a new medicine. What other medicines were they taking prior to start of the new medicine? These are markers of disease and, in the case of some medicines, disease severity. ${ }^{13}$ What other medicines are they prescribed after they start taking the new medicine? An unexpected side-effect of a new medicine could be revealed if we saw that many patients getting the new medicine were soon thereafter prescribed another type of medicine. ${ }^{14}$

If some of the patients prescribed a new blood pressure medicine were then prescribed an anti-depressant a few weeks later, one might reasonably suspect that depression, or some mental change resembling depression, was a side-effect of the new blood pressure medicine.

One of the great advantages of the pharmacy information is that it does not rely on anyone's special initiative to report 
when something unusual is suspected about medicine. We know, for example, that only about $10 \%$ of doctors, at the most, report adverse reactions to prescription medicines. That low rate of reporting has been one of the limitations of spontaneous reporting systems. Pharmacy records cannot identify all possible adverse reactions, but those that are identifiable from prescribing patterns can be searched for in all recipients of the medicine. The result would appear to be a good complement to voluntary reporting, with the additional advantages of being fast and inexpensive.

Another role of the prescription drug history is to provide reliable information when the patient goes to hospital. Paulien Van Hessen, Hans Petri, and I recently found important omissions in drug prescribing to one patient in about 17 admitted to hospital electively. ${ }^{55}$ Walter Nimmo and his colleagues studied this in Glasgow several years ago and found that, with emergency admissions to the surgical service, one patient in about fout had crucial omissions in drug prescribing in hospital. ${ }^{16}$

\section{Pilot Program in "Sentinel Pharmacies"}

From the work that we and our Utrecht colleagues have done on various aspects of the Dutch community pharmacy as an informational resource, $I$ urge that about 20 Dutch pharmacies be designated "sentinel pharmacies" in a pilot program to explore the benefits and costs of running an ongoing program of survellance on new medicines. I belleve that it can improve the understanding of how new medicines are used as they enter the market, that it can help identify unexpected effects of a new medicine (good or bad), and that it can complement the spontaneous reporting system which has been the mainstay for surveillance of new medicines. It can also explore the value of routinely providing a reliable prescription drug history when patients enter hospital, both electively and in emergencies. 


\section{In Conclusion}

We have seen how technology has changed the concept of a medicine, with information now the pre-eminent attribute. The economics of medicines are no longer dominated by chemical manufacturing, but by the acquisition and management of information. The same forces are acting to transform the Dutch community pharmacy from its traditional role solely as a dispenser of medicines to being not only a dispenser of information, but a primary source of information integrated as nowhere else in the health care system. Our recent studies show some of the values of this information. In my visionary mode, I foresee reimbursement for pharmacy-derived information as a growing factor in pharmacy economics. It is a challenge to pharmacy to pursue this vision and build public recognition of its values.

We have also seen something of the past and a glimpse at the future of regimen optimization. The ability to monitor many variables in ambulatory patients opens new opportunities in pharmacodynamics to observe and analyze the clinical correlates of patients' natural experiments in dose-timing.

We have also seen in the example of nifedipine how research on regimen optimization can guide the design of drug delivery systems to improve the therapeutic porential of an established drug substance. This is a valuable pathway of pharmaceutical innovation because it builds on an established drug's record of safety-degree that can only come from clinical experlience in hundreds of thousands or millions of patients -. a record of priceless value. Seen in this light, the recent decision to reimburse at uniform price for each drug substance is very shortsighted. It says to the industry: we will repay your investment in new drug substances, but we won't repay your investment in tying to improve the therapeutic potential of drug substances with well-proven safery records. While new drug substances hold out the promise of new therapeutic potential, they enter the market with only a minimally defined degree of 
safety, because they have been tested in only a few thousand carefully selected patients. We should rejoice when someone finds unexpected therapeutic walue in an elderly drug with a well-understood degree of safety. Such innovations have unique value which should be reflected in their pricing in the marketplace. The decision to set reimbursement by drug substance ignores those values. How can that be in the public's interest?

As you have seen, I come from a mixed academic and industrial background, with many distinguished colleagues in a variety of fields. My physiological mentors have been $F$. Eugene Yates, then at Harvard; James O. Davis, then at the National Institutes of Health; Ernst Knobil, then at Pittsburgh. My mentors on the industrial side have been two of the great entrepreneurs in biomedical innovation; Alex Zaffaroni at ALZA and Ray Williams at APREX. My mentors in epidemiology have been Ferd Sturmans and Paul Knipschild at RL, Alvan Feinstein at Yale, and the late John Snow through his epochal book on cholera. Ellen Weber and Wolfgang Krüse at Heidelberg did some of the first and most thought-provoking studies with the electronic monitors of dose-timing. The fine integrative mind of Harry Struyker-Boudier attracted me to Maastricht, at first, and still continuing, for pharmacological reasons, then for a joint effort in writing a book about risk analysis. ${ }^{17}$ The book originated in my long and fruitful collaboration with Klaus Heilmann in Munich. The ideas developed in the book helped us to see the opportunities for pharmacoepidemiology here at the University. Hans Petri and Rieki de Vet helped me recognize the Dutch pharmacy as a unique informational resource, and Hans has played the key role in carrying out our research. If my vision for Dutch pharmacy comes anywhere near fruition, Jack Naus at Nederweert should be given a special medal by the KNMP. Albert Bakker and Bert Leufkens at Utrecht have been valuable collaborators who have contributed important ideas and greatly expanded the scope of the work. Douwe Breimer's research insights and counsel have been invaluable. My wife, Joan Urquhart, who 
bears many burdens and provides great help and support to me, our children, and our grandchildren, has taught me to look and listen with much more care than instinct would have had it.

Lastly, I thank both the Stichting Farmaco-epidemiologie and Rijksuniversiteit Limburg for their confidence and support reflected in my appointment. I hope that my work and service here will continue to merit favorable judgment. 


\section{Bibliography}

1. Webster's Collegtate Dictionary, Fifth Ed. Springfield MA: GSC Merriam, 1944 (Gift of my mother, Christmas 1944).

2. TRANSDERM-SCOP, scopolamine. Physicians' Desk Reference. Montrale: Medical Economics, 1992, p. 887-9.

3. Urquhart J. Development of the OCUSERT pilocarpine ocular therapeutic systems - a case history in ophthatmic product development In: Ophthalmic Drug Delivery Systems. Ed: Robinson JR. Washington DC: American Pharmaceurical Association, 1980, p. 105 et seq.

4. PROCARDIA XL, nifedipine. Physicians" Desk Reference. Montwale: Medical Economics, 1992, p. 1783.5. Compare the side effect incidence figures for the two forms given in the two tables and text on p. 1784.

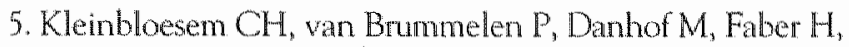
Urquhart J, Breimer DD. Rate of increase in the plasma concentra. tion of nifedipine as a major determinant of its hemodynamic effects in humans. Clin Pharmacol Ther 41:26-30, 1987.

6. Temple R. Dose-response and registration of new drugs. In: Doseresponse relationships in clinical pharmacology. Eds: Lasagna $L$, Erill S. Naranjo CA. Amstendam: Elsevier, 1989, pp. 145.167.

7. The documentation for this story is to be found in the time history of changing dosage recommendations for the two drugs in successive annual wolumes of a drug compendium, stuch as the Physicians" Desk Reference or the British National Formulary, from 1980 onward.

8. This story is told in very concise terms in the following reference: Crease GW, Jaffe ME. Pulsatile delivery systems. Ann NY Acad Sci 68:548-57. This paper indudes the key references to Emst Knobil's work that identitied the pulsatile secretion of GnRH by the hypothatamus. 
9. Urquhart J. Fourteenth Bowditch Lecture to the American Physiological Society: Blood-bome signals -- the measuring and modeling of humoral communication and control. Physiologist 13.7 et seq., 1970.

10. Sheinet $L B$. The intellectual health of clinical drug evaluation. Clin Pharmacol Ther 50:4.9, 1991.

11. The following reference is a good summary: Urquhart ]. Realtime compliance monitoring in clinical trials: methods, early results, prospects. Human Psychophamacology, v. lll. Ed: Hindmarch I, Stonier P. Chichester (UK): John Wiley, 1990, pp. 129-147.

12. Grabowski H. Pharmaceutical research and development: returns and risks. CMR Annual Lecture, 1991. Centre for Medicines Research, Carshalton, Surrey, UK.

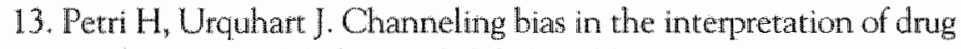
effects. Statistics in Medicine 10.577-81, 1991.

14. Petri $H$, Leufkens $H$, Naus J, Silkens $R$, van Hessen $P$, Urquhart J. Rapid method for estimating the risk of acutely controversial side effects of prescription drugs. I Clin Epidemiol 43:433-9, 1990.

15. Van Hessen P. Petri H, Urquhart J. Do prescribed drugs always follow the patients to hospital? Pharm Weekbl Sc Ed 12:66-70, 1990.

16. Duthe DJR, Montgomery IN, Spence AA, Nimmo WS. Concurrent drug therapy in patients undergoing surgery. Anaesthesia 42:305-6, 1987.

17. Sruyker-Boudier H, Heilmann K, Urquhart J. Risko's Meten. Baam: In den Toren, 1985. This is the Dutch version of the book whose original version was published in 1983 by Klaus Heilmann and me as Keine Angst vor der Angst (Munich: Kindler) and in 1984 by me and Heilmann as Risk Watch .. The Odds of Life (New York: Facts on File). Each language-version describes ways to simplify risk communication for better public understanding, though differently written to reflect national concerns about technology-related hazards. 